\title{
Inorganically Precipitated Phosphates and Carbonates to Improve Porous Material Properties
}

\author{
Debendra Neupane, ${ }^{\mathrm{a}}$ Hideaki Yasuhara,${ }^{\mathrm{b} *}$, Heriansyah Putra, ${ }^{\mathrm{c}}$ Naoki Kinoshita,${ }^{\mathrm{d}}$ \\ aPenta-Ocean Construction Co., LTD. Email: deben646@yahoo.com \\ bepartment of Civil and Environmental Engineering, Faculty of Engineering, Ehime University. Email: yasuhara.hideaki.me@ehime-u.ac.jp \\ 'Department of Civil and Environmental Engineering, Faculty of Agricultural Technology, Bogor Agricultural University. \\ Email: heriansyahptr@apps.ipb.ac.id \\ dDepartment of Civil and Environmental Engineering, Faculty of Engineering, Ehime University. Email: kinoshita.naoki@ehime-u.ac.jp
}

\begin{abstract}
Inorganically precipitated metal phosphate and metal carbonates may improve the physical and mechanical properties of the porous materials. Two types of porous materials i.e., sand and concrete, are examined. The phosphate and carbonate minerals of calcium and magnesium are appraised. Two series of experiments are conducted. In the first series of experiments, the efficacy of the inorganic grout is examined to improve the mechanical properties of sandy soil. In the second series of experiments, the efficacy of the inorganic phosphate to reduce the permeability of concrete is evaluated. The potential of these combinations is also appraised to reduce the permeability through the concrete cracks. The results exhibit that the reduction of the permeability through the cracks up to 3 orders of magnitude is possible.
\end{abstract}

Keywords: Carbonate; crack sealing; phosphate; inorganic precipitation; soil improvement

\section{Introduction}

Soil is the foundation of almost all engineering projects. For the safe and proper functioning of the civil engineering structures, they should be founded on firm soil. The physical and mechanical properties of soil should meet certain requirements for the structures to be founded on it. The properties of soils may not always be adequate. Soil improvement is necessary in places where the soils do not meet the engineering requirements. Grouting should be one of the solutions, and the development of a new grunting technique is aimed in this work.

Chemical grouting has been studied for its various possible applications such as preservation of the limestone monuments [1], plugging up the pores of oil recovery reservoir rocks and removing the contaminants in groundwater systems [2], repairing the cracks in concrete [3], reducing the swelling potential of clayey soil, mitigation of the liquefaction potential of soil [4], [5], and soil permeability control and improvement [6]-[10].

\footnotetext{
${ }^{*}$ Corresponding author. Tel.: +81-89-927-9853

3, Bunkyo-cho, Matsuyama, Japan, 790-8577
}

Research on carbonate and phosphate precipitation and their solidification has been conducted as potential soil improvement and permeability control technique. The precipitation within the soil samples reduced the permeability significantly [8], [9]. Application of calcium phosphate compound (CPC-chem) have been reported as a promised method for as the soil improvement technique [5], [11], [12]. The CPC-chem has the two unique characteristics; its $\mathrm{pH}$ is dependent on its solubility and it exhibits a self-setting mechanism [13]. In addition, the CPCchem is easy to obtain, safe to handle, non-toxic, and recyclable. Therefore, it may be one of the suitable materials for civil engineering applications [5].

Concrete is used as most popular construction materials all over the world. The maintenance of the constructed concrete is a main issue for our sustainable society. Novel methodology to repair the cracked concrete is required for this purpose. In this work, various chemicals which are expected to give carbonates and phosphate minerals of calcium and magnesium are examined. The combinations that produce hard crystals and that have considerable time before the precipitation begins are selected. Small scale sand samples are prepared and treated with the newer grout. The newer grout is also evaluated for its possible application in lowering the permeability through the cracked concrete. 


\section{Precipitation test}

The main objective of the experiments presented in this work is to evaluate the methods of mineral precipitation. Mineralized phosphates and carbonates are produced by allowing soluble salts of calcium and magnesium to react with soluble carbonates, bicarbonates and phosphates. The chemicals utilized in this study are summarized in Table 1.

Table 1. Summary of the evaluated chemicals.

\begin{tabular}{cccc}
\hline Soluble metal salts of & $\begin{array}{c}\text { Soluble } \\
\text { carbonate, } \\
\text { bicarbonate } \\
\text { and phosphate }\end{array}$ & $\begin{array}{c}\mathrm{pH} \\
\text { controller }\end{array}$ \\
\hline $\mathrm{CaCl}_{2}$ & Magnesium & $\mathrm{Na}_{2} \mathrm{CO}_{3}$ & $\mathrm{NaOH}$ \\
$\mathrm{Ca}\left(\mathrm{NO}_{3}\right)_{2}$ & $\mathrm{Mg}_{2}\left(\mathrm{NO}_{3}\right)_{2}$ & $\mathrm{NaHCO}_{3}$ & $\mathrm{NH}_{4} \mathrm{OH}$ \\
& $\mathrm{MgSO}_{4}$ & $\mathrm{NaH}_{2} \mathrm{PO}_{4}$ & \\
\hline
\end{tabular}

The precipitated materials are evaluated directly in the transparent PP (polypropylene) tubes. Several chemical combinations are appraised. The combinations that bring about an insoluble, crystalline material at the bottom of the tubes are shown in Table 2. The concentrations of reagents are selected by following the expected chemical equations in a way to obtain the final product concentration of $0.5 \mathrm{~mol} / \mathrm{L}$. Various combinations of chemicals, as shown in Table 1, are mixed thoroughly in PP tubes. The final volume of the mixed solution is $30 \mathrm{~mL}$. The solution is allowed to react for two days in room temperature. After two days, the crystalline materials and the supernatant are separated. The crystalline materials are washed and dried in room temperature. Hard insoluble materials as shown in Fig. 1 are obtained. The precipitated materials may bind with soil particles to improve the mechanical properties of sandy soil. The precipitated material may plug the pore/cracks in concrete to reduce its permeability.

Table 2. Selected combinations for small cylinder experiment.

\begin{tabular}{ccccc}
\hline $\begin{array}{c}\text { Exp. } \\
\text { name }\end{array}$ & $\begin{array}{c}\text { Chemical A } \\
{[0.5 \mathrm{~mol} / \mathrm{L}]}\end{array}$ & $\begin{array}{c}\text { Chemical B } \\
{[1.0 \mathrm{~mol} / \mathrm{L}]}\end{array}$ & $\begin{array}{c}\mathrm{pH} \\
\text { controller C }\end{array}$ & $\begin{array}{c}\text { Expected } \\
\text { precipitate } \\
{[0.5 \mathrm{~mol} / \mathrm{L}]}\end{array}$ \\
\hline In24 & $\mathrm{Mg}\left(\mathrm{NO}_{3}\right)_{2}$ & $\mathrm{NaHCO}_{3}$ & - & $\mathrm{MgCO}_{3}$ \\
In25 & $\mathrm{Mg}\left(\mathrm{NO}_{3}\right)_{2}$ & $\mathrm{NaHCO}_{3}$ & $\mathrm{NaOH}(0.10)$ & $\mathrm{MgCO}_{3}$ \\
In28 & $\mathrm{MgSO}_{4}$ & $\mathrm{NaHCO}_{3}$ & $\mathrm{NaOH}(0.10)$ & $\mathrm{MgCO}_{3}$ \\
In29 & $\mathrm{MgSO}_{4}$ & $\mathrm{NaHCO}_{3}$ & $\mathrm{NH}+\mathrm{OH}(0.15)$ & $\mathrm{MgCO}_{3}$ \\
P-13 & $\mathrm{NaH}_{2} \mathrm{PO}_{4}$ & ${\mathrm{Mg}\left(\mathrm{NO}_{3}\right)_{2}}$ & $\mathrm{NaOH}(0.25)$ & $\mathrm{Mg}\left(\mathrm{H}_{2} \mathrm{PO}_{4}\right)_{2}$ \\
P-16 & $\mathrm{NaH}_{2} \mathrm{PO}_{4}$ & $\mathrm{MgCl}_{2}$ & $\mathrm{NaOH}(0.4)$ & $\mathrm{Mg}\left(\mathrm{H}_{2} \mathrm{PO}_{4}\right)_{2}$ \\
\hline
\end{tabular}

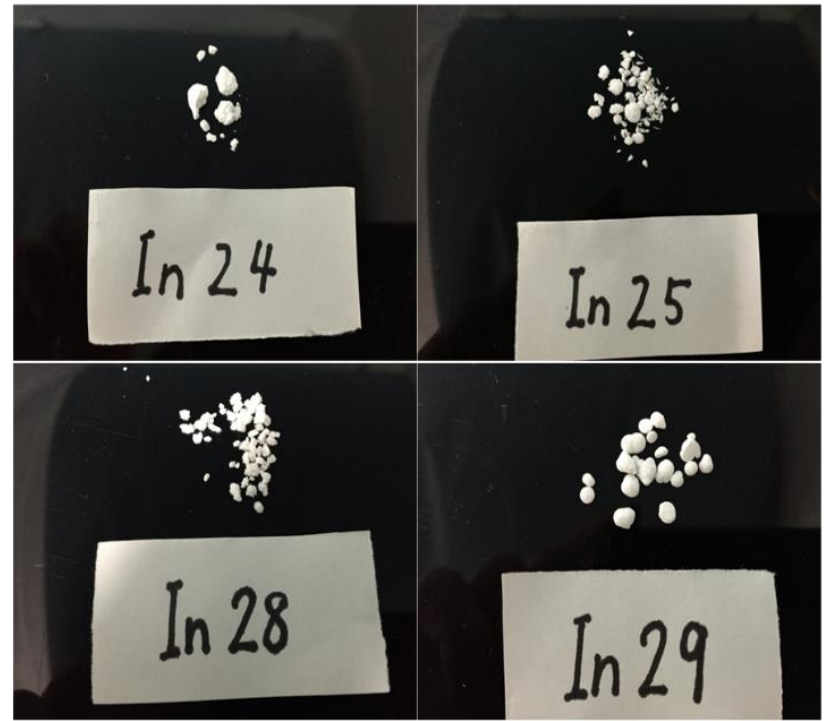

Figure 1. Precipitated materials of the selected combinations.

\section{Small cylinder experiment}

Cylindrical PVC (polyvinyl chloride) molds with a diameter of $50 \mathrm{~mm}$ and a height of $100 \mathrm{~mm}$ are utilized to prepare sand specimens. $300 \mathrm{~g}$ of silica sand (keisha \#6) is carefully pluviated in air to acquire a relative density of 50 $\%$. The grain size distribution of the sand used is shown in Fig. 2. Grout solutions $\mathrm{A}$ and $\mathrm{B}$, and catalyst $\mathrm{C}$ as shown in Table 2 are blended together. One pore volume of the blended solution (i.e., grout) is poured into the dry sand specimens. Pouring is continued three times at an interval of 24 hours. After 24 hours of the final pouring, $150 \mathrm{~mL}$ of distilled water is poured to flush out the by-products. Distilled water is allowed to drain out for another 24 hours, and finally sand specimens are removed of the mold. The improvement in the treated soil specimens is observed. The specimens are capable to self-stand as shown in Fig. 3. Although hard and crystalline materials are obtained in the precipitation test, these materials are not found capable of improving the soil strength noticeably.

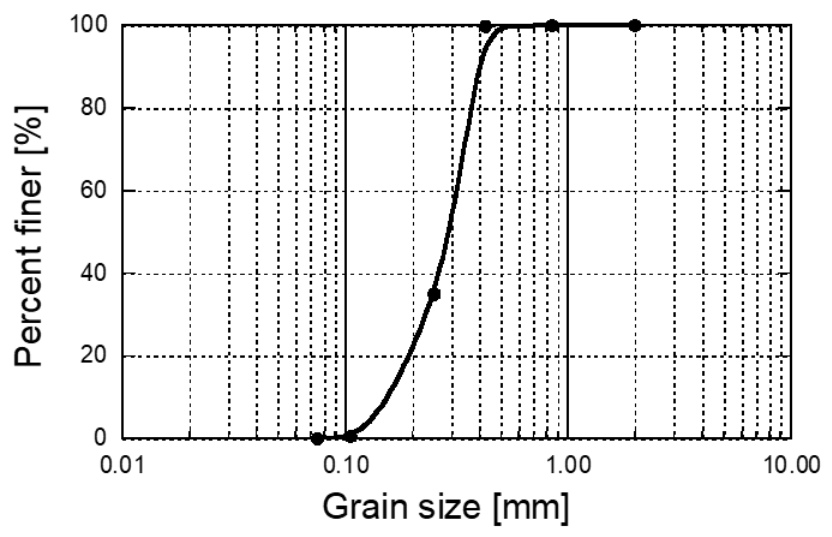

Figure 2. Grain size distribution of sand. 
After conducting six experiments we came into conclusion that the precipitated materials, in spite of their hardness, in normal condition are poorly capable to adhere with or bind the grains of the silica sand utilized in this experiment. The SEM images shown in Fig. 4 show that a very small fraction of precipitated materials take part in making connections between the soil particles making anchors with each other. Further research is required to achieve a good bonding from the inorganically precipitated materials.

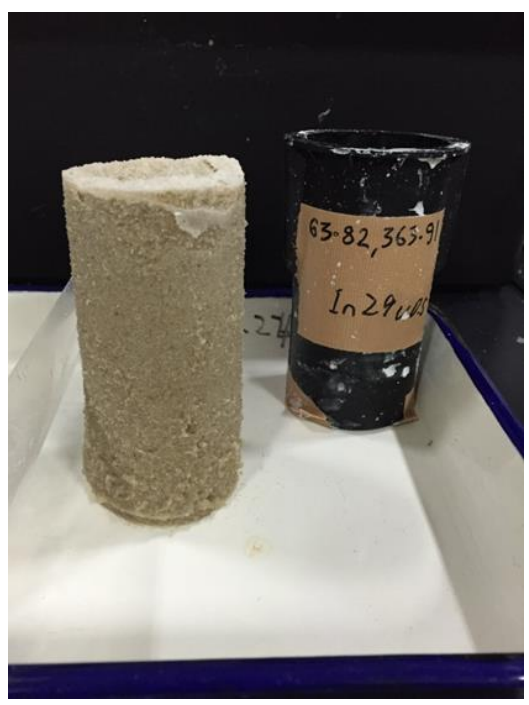

Figure 3. Self-standing treated specimen.
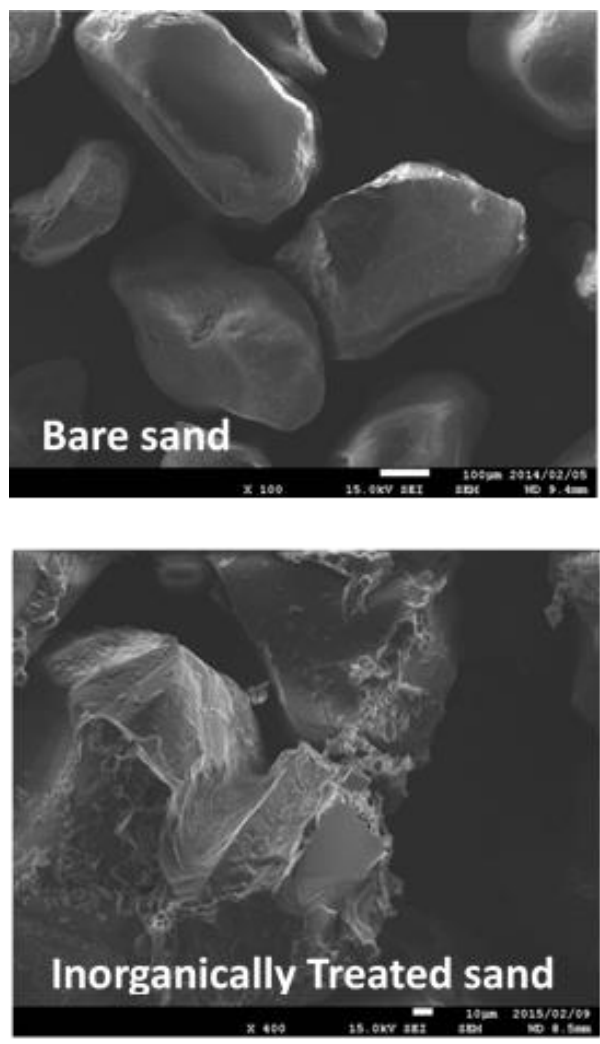

Figure 4. SEM image of bare sand and inorganically treated sand.

\section{Concrete permeability test}

Cracks in concrete act as pathways that allow water and other aggressive chemicals to penetrate through it, enabling its deterioration [14]. Highly permeable concrete cracks increase the risk of damage due to freezing and thawing. The permeability of the hydraulic structures should be well controlled to reduce seepage. The mineralized phosphate grout which may reduce the permeability of the cracked concrete by plugging the cracks and fractures is evaluated. The method of reducing permeability helps to improve the resistance to chemical problems, such as sulphate attack, chloride ion penetration.

The evaluated grout is composed of a mixture of $\mathrm{NaH}_{2} \mathrm{PO}_{4}$ and $\operatorname{Mg}\left(\mathrm{NO}_{3}\right)_{2}$. In this method, the rate of precipitation can be controlled by adding $\mathrm{NaOH}$ to $\mathrm{NaH}_{2} \mathrm{PO}_{4}$ solution before mixing with $\mathrm{Mg}\left(\mathrm{NO}_{3}\right)_{2}$. A concentration of $0.2 \mathrm{~mol} / \mathrm{L}$ of $\mathrm{NaOH}$ is adjusted in this study in a way that the precipitation starts to occur after about 4 hours of mixing. The expected reaction is given in Eq. 1 .

$$
2 \mathrm{NaH}_{2} \mathrm{PO}_{4}+\mathrm{Mg}\left(\mathrm{NO}_{3}\right)_{2} \rightarrow \mathrm{Mg}\left(\mathrm{H}_{2} \mathrm{PO}_{4}\right)_{2}+2 \mathrm{NaNO}_{3}
$$

The permeability reduction method may be applicable in mass concrete where fast setting grouts and grouts with high viscosity cannot reach the required depth of concrete. Since the rate and time of precipitation can simply be controlled by adjusting the concentration of $\mathrm{NaOH}$. This method may also be applicable to plug the fractured rock in the underground rock cavern for petroleum storage.

\subsection{Experimental procedure}

Concrete cylinders with a diameter of $10 \mathrm{~cm}$ and a height of $20 \mathrm{~cm}$, in PVC pipes with an internal diameter of $10 \mathrm{~cm}$ and a height of $30 \mathrm{~cm}$ are utilized. The schematic of the prepared specimen is shown in Fig. 5.

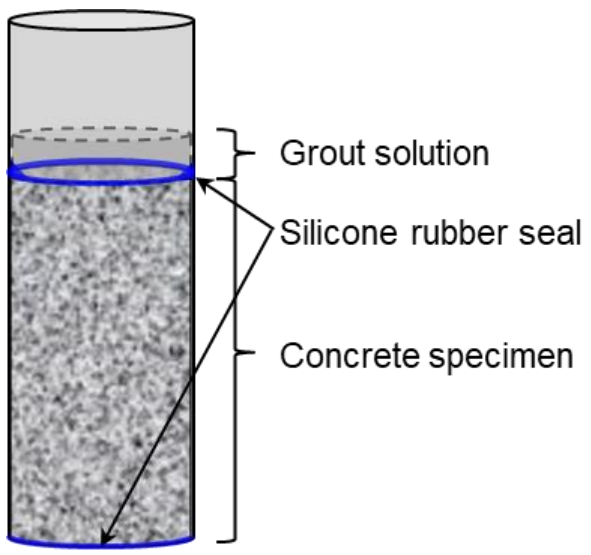

Figure 5. Schematic of the concrete specimen.

The specimens are cracked in splitting tensile testing machine (Brazilian Test machine) as shown in Fig. 6. The space in between the concrete specimen and the PVC pipe is sealed with silicone rubber as shown in Fig. 5. The silicone 
rubber is allowed to set for 1 day. The specimen is immersed in water for 7 days to make it fully saturated. The initial permeability of the specimen is evaluated.
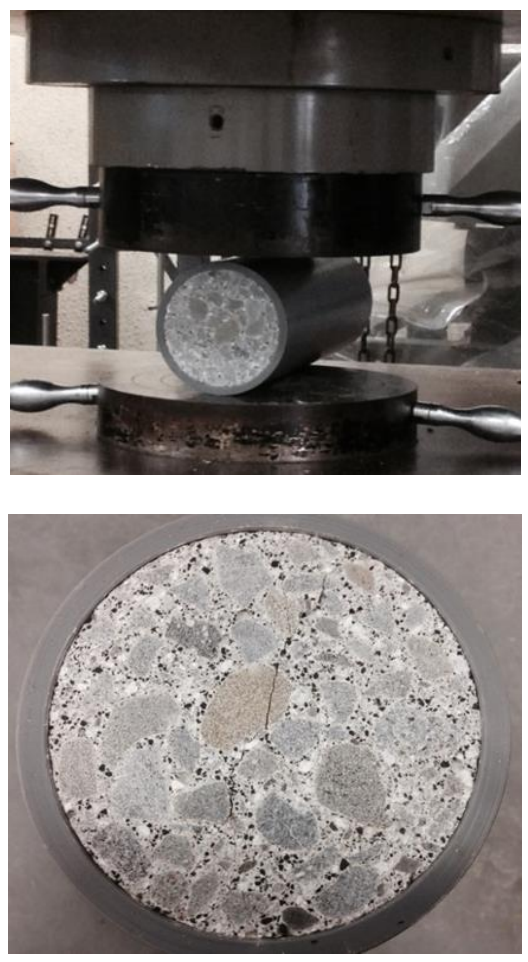

Figure 6. Preparation of the cracked concrete specimen

The schematic for the permeability experiment is shown in Fig. 7. As illustrated in the figure, the PVC pipe with concrete specimen is set in an arrangement which allows to inject and drain the water. A water tank and adjustable pressure pump is mounted in the injection side. The drained water is collected in a beaker set on a weighing machine. The weighing machine is connected to a data logger which records the flow through the specimen at every 5 seconds. Different injection pressure is applied for different specimens. The injection pressure depends upon the flow rate through the specimens. If the flow rate is high, low pressure is maintained and if the flow rate is low relatively higher pressure is maintained. For a specimen with a wide crack, several centimetres pressure head was enough to maintain the flow. For the specimen with very low flow rate, such as treated specimens, the pressure required to maintain the flow should be several tens of $\mathrm{kPa}$.

After the evaluation of the initial permeability, the specimen is removed from the permeability experiment setup to inject the grout. $100 \mathrm{~mL}$ freshly prepared grout solution is poured from the surface of the specimen as shown in Fig. 5 . The grout is freely allowed to permeate through the cracks for two days. Grout is injected three times at an interval of every two days. Before the application of second and the third grout, the solution retained above the specimen, and the predicated material on the surface are removed. The top surface should be cleaned before the new injection, otherwise the precipitated material restricts the fresh grout to flow into the cracks. Similarly, the older grout solution may affect the reaction rate of the newly injected grout solution which is not desirable. After completing the third grout application, the retained solution and the precipitated material at the concrete surface are removed. The specimen is arranged to permeability test set-up, and the final permeability test is conducted.

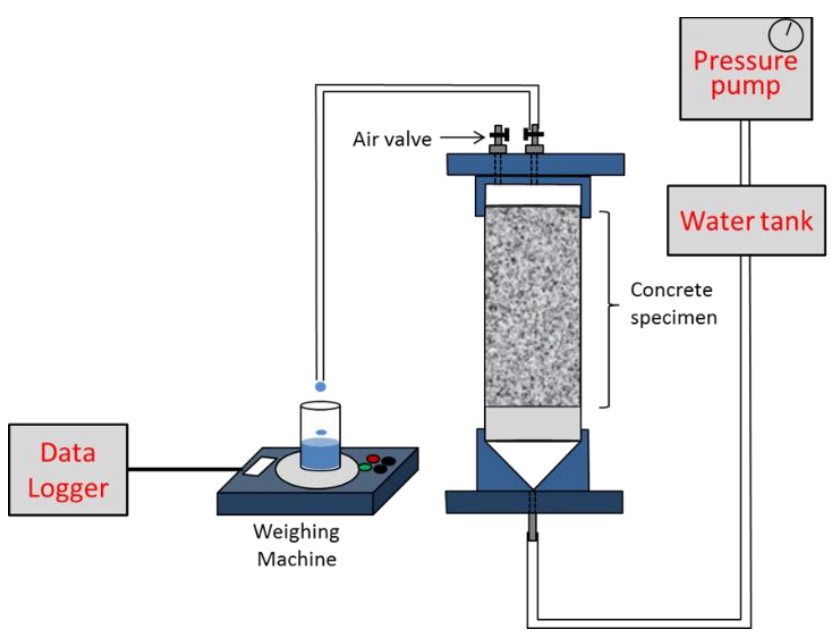

Figure 7. Schematic of the permeability experiment.

\subsection{Results and discussion}

Summary of the concrete specification, grout composition and grout application are given in Table 3 . Altogether 6 specimens are experimented. Experiment P1 and $\mathrm{P} 2$ are conducted to examine the distribution of the grout inside the concrete along the major cracks. After the treatment, specimens are removed from the PVC mold and broken along one of the major cracks using split tensile test (Brazilian Test) machine. The distribution of the grout along one of the major cracks is shown in Fig. 8. As is apparent in Fig. 8, the grout is observed to distribute throughout the length of the specimen.

Table 3. Summary of the permeability test.

\begin{tabular}{ll}
\hline $\begin{array}{l}\text { Specimen size } \\
\text { Immersed in water }\end{array}$ & $\begin{array}{l}\phi=100 \mathrm{~mm}, \mathrm{~h}=195 \mathrm{~mm} \\
\text { for } 7 \text { days } \\
\text { Solution injection }\end{array}$ \\
& $100 \mathrm{~mL}$ each, 3 times at an interval of every \\
& $\mathrm{NaH}_{2} \mathrm{PO}_{4}[1.0 \mathrm{~mol} / \mathrm{L}]+$ \\
& $\mathrm{Mg}\left(\mathrm{NO}_{3}\right)_{2} .6 \mathrm{H}_{2} \mathrm{O}[0.5 \mathrm{~mol} / \mathrm{L}]+$ \\
Grout content & $\mathrm{NaOH}[0.2 \mathrm{~mol} / \mathrm{L}]$ \\
\hline
\end{tabular}




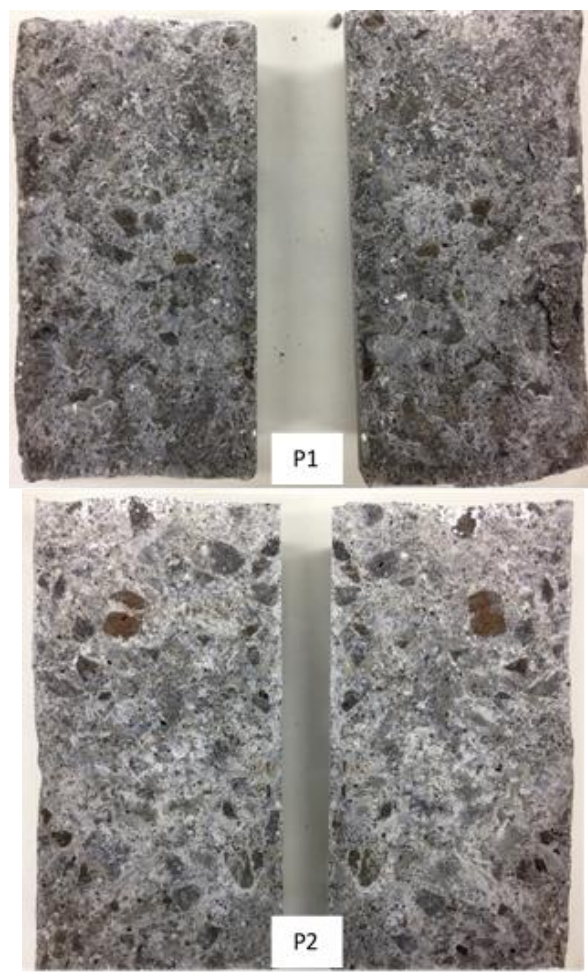

Figure 8. Treated specimens is cut along one of the major crack (white material is phosphate).

Experiment P3 and P4 are conducted to evaluate the evolution of permeability. The comparison of the flow rates through the concrete specimen before and after treatment are shown in Fig. 9. The flow rates are consistent for given water pressures which validates the permeability test results. The flow rate has been noticeably reduced after treatment. As shown in Fig. 9 (P3), flow occurs at low heads $(15 \mathrm{~cm})$ before the treatment. However, after the treatment, flow occurs only at high head $(9 \mathrm{kPa})$. Moreover, discharge is very low after the treatment even at a relatively higher pressure (i.e., $82 \mathrm{kPa}$ ) in case of $\mathrm{P} 4$.

The change in permeability of the concrete specimens before and after the treatment is shown in Fig. 10. As is observed in the figure, remarkable reduction of permeability is obtained through the treated concrete specimens. The reduction of permeability is up to 3 orders of magnitude. The final hydraulic conductivity obtained in case of $\mathrm{P} 4$ is $5.99 \times 10^{-6} \mathrm{~cm} / \mathrm{s}$. The equivalent permeability equals $6.11 \times 10^{-15}$. The permeability of the treated concrete is nearly equal to the permeability of the intact concrete. These results show that the method of phosphate grouting is capable of reducing the permeability of the concrete specimens considerably.
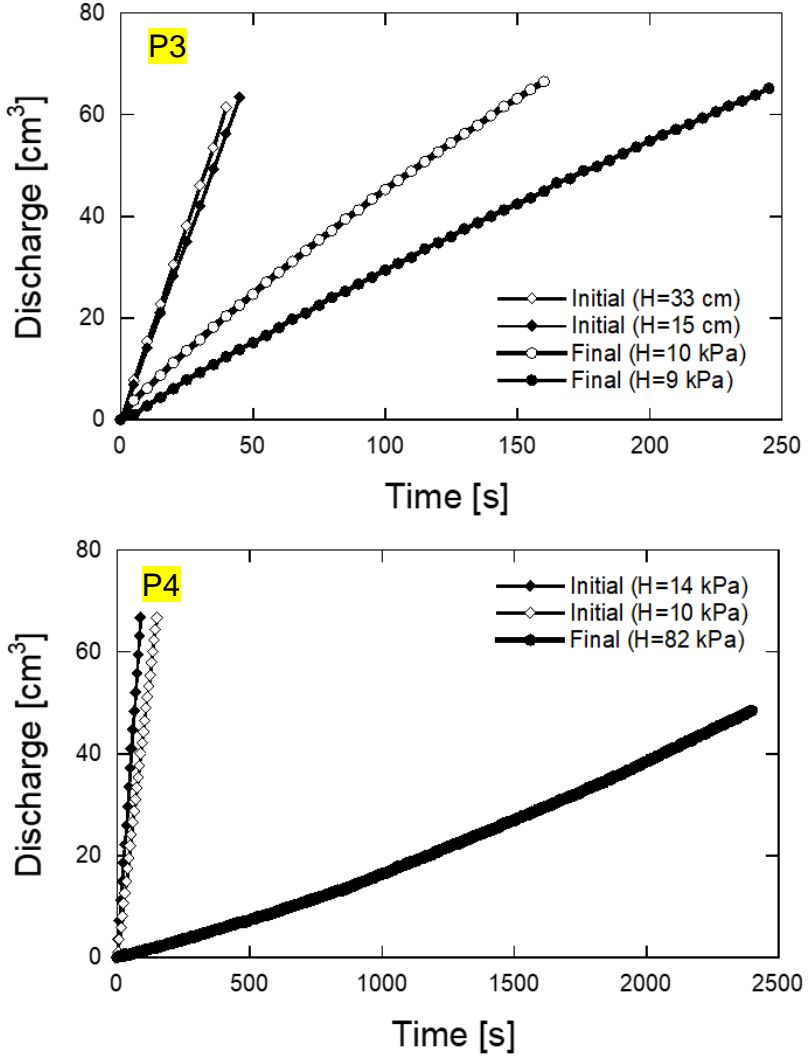

Figure 9. Initial and final flow rate through the concrete specimens (P3 and P4).

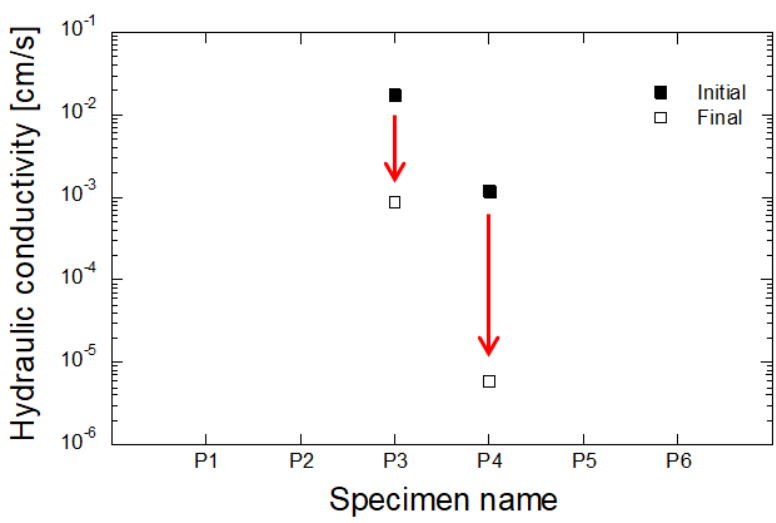

Figure 10. Initial and final permeabilites of the treated samples.

\section{Conclusions}

Inorganically precipitated minerals of phosphates and carbonates were appraised. The inorganic reactions were relatively simple and easy to control in comparison with the organic reactions. Inorganically precipitated materials were used to evaluate the mechanical properties of treated soil specimens. The soil specimens treated with inorganic grout were able to self-stand.

Afterwards, inorganic grout was utilized to reduce the permeability of the cracked concrete specimens. Cracked concrete specimens were treated three times with grout. 
Permeability of the specimens before treatment and after treatment was measured. An appreciable reduction in permeability was achieved in the treated sample. The reduction in permeability was up to 3 orders of magnitude. The injected grout was also found to distribute uniformly along the cracked surface which showed the uniformity of this grouting technique. This method may be useful to plug the cracked concrete for enhancing its hydraulic performance.

\section{Acknowledgements}

This work has been partly supported by research grant from the Penta-Ocean Construction Co., LTD., Tokyo, Japan. This support is gratefully acknowledged.

\section{References}

[1] S. M. Al-Thawadi, "Ureolytic Bacteria and Calcium Carbonate Formation as a Mechanism of Strength Enhancement of Sand," J. Adv. Sci. Eng. Res., vol. 1, pp. 98-114, 2011.

[2] M. Nemati, E. A. Greene, and G. Voordouw, "Permeability profile modification using bacterially formed calcium carbonate: comparison with enzymic option," Process Biochem., vol. 40, no. 2, pp. 925-933, Feb. 2005

[3] W. De Muynck, D. Debrouwer, N. De Belie, and W. Verstraete, "Bacterial carbonate precipitation improves the durability of cementitious materials," Cem. Concr. Res., vol. 38, no. 7, pp. 1005 1014, Jul. 2008

[4] V. Ivanov and J. Chu, "Applications of microorganisms to geotechnical engineering for bioclogging and biocementation of soil in situ," Rev. Environ. Sci. Bio/Technology, vol. 7, no. 2, pp. 139-153, Jun. 2008.

[5] M. Akiyama and S. Kawasaki, "Novel grout material comprised of calcium phosphate compounds: In vitro evaluation of crystal precipitation and strength reinforcement," Eng. Geol., vol. 125, pp.
119-128, Jan. 2012

[6] V. S. Whiffin, L. A. van Paassen, and M. P. Harkes, "Microbial Carbonate Precipitation as a Soil Improvement Technique," Geomicrobiol. J., vol. 24, no. 5, pp. 417-423, Aug. 2007.

[7] J. T. DeJong, B. M. Mortensen, B. C. Martinez, and D. C. Nelson, "Biomediated soil improvement," Ecol. Eng., vol. 36, no. 2, pp. 197-210, Feb. 2010.

[8] H. Yasuhara, D. Neupane, K. Hayashi, and M. Okamura, "Experiments and predictions of physical properties of sand cemented by enzymatically-induced carbonate precipitation," Soils Found., vol. 52, no. 3, pp. 539-549, Jun. 2012.

[9] H. Putra, H. Yasuhara, N. Kinoshita, and A. Hirata, "Application of magnesium to improve uniform distribution of precipitated minerals in 1-m column specimens," Geomech. Eng., vol. 12, no. 5, pp. 803-813, 2017.

[10] L. A. Van Paassen, M. P. Harkes, G. A. Van Zwieten, W. H. Van Der Zon, W. R. L. Van Der Star, and M. C. M. Van Loosdrecht, "Scale up of BioGrout: A biological ground reinforcement method," in Proceedings of the 17th International Conference on Soil Mechanics and Geotechnical Engineering: The Academia and Practice of Geotechnical Engineering, 2009.

[11]E. Fernández, F. J. Gil, S. M. Best, M. P. Ginebra, F. C. M. Driessens, and J. A. Planell, "Improvement of the mechanical properties of new calcium phosphate bone cements in the CaHPO 4 - $\square$-Ca 3 (PO 4 ) 2 system: Compressive strength and microstructural development," $J$ Biomed Mater Res, vol. 41, pp. 560-567, 1998.

[12]M. Akiyama and S. Kawasaki, "Microbially mediated sand solidification using calcium phosphate compounds," Eng. Geol., vol. 137-138, pp. 29-39, Jun. 2012.

[13]M. S. Tung, "Calcium Phosphates: Structure, Composition, Solubility, and Stability," in Calcium Phosphates in Biological and Industrial Systems, Z. Amjad, Ed. Boston, MA: Springer US, 1998, pp. 1-19.

[14]C.-M. Aldea, S. P. Shah, and A. F. Karr, "Permeability of cracked concrete," Mater. Struct., vol. 32, pp. 370-376, 1998. 